\title{
The Influence of Foliar Application of Biostimulant Atonik and Different Sources of Potassium on Full Sun and Partial Shade Salvia farinacea Plants
}

\author{
Amaal A. M. Heikal \\ Department of Ornamental Horticulture, Faculty of Agriculture, Cairo University, \\ Cairo, Egypt.
}

\begin{abstract}
$\mathrm{N}^{2}$ UTRITION and some environmental variables play a major role in the growth and development of ornamental plants. Two pot experiments were carried out in a randomized complete block design to study the effect of foliar application of biostimulator agent (Atonik, $0.2 \%)$ and different sources of potassium viz. potassium sulphate $(2 \mathrm{~g} / \mathrm{L})$, potassium citrate $(2 \mathrm{~g} / \mathrm{L})$ and potassium humate $(3 \mathrm{~g} / \mathrm{L})$ on growth parameters and chemical constituents of Salvia farinacea plants grown under full sun and/or partial shade conditions (50\% shade) during 2014/15 and 2015/16 seasons.
\end{abstract}

Foliar application of atonic and different sources of potassium enhanced growth, chlorophyll, total carbohydrates and mineral contents of plants grown in both environments. Under full sun, spraying plants with $\mathrm{K}$ humate gave the highest number of leaves and inflorescences as well as the highest biomass of fresh and dry leaves, while under partial shade, spraying plants with $\mathrm{K}$ citrate + atonik gave the highest values of these traits. Foliar application of K citrate + atonik gave the highest values of fresh and dry weight of inflorescences in both environments. Plants grown under partial shade conditions were superior in plant height and individual leaf area, while those grown under open field conditions were superior in stem diameter, number of leaves, branches, roots and inflorescences per plant, fresh and dry weight of leaves, stems, roots and inflorescences per plant as well as chlorophyll, total carbohydrates and mineral contents.

Keywords: Blue Sage Plant, Asahi SL, Potassium Nutrition, Light Conditions, Growth, Flowering.

\section{Introduction}

Mealy Blue Sage, Salvia farinacea, also known as Mealycup Sage. It is one of the most herbaceous perennial valued love flowers of the family Lamiaceae, native to New Mexico and Texas. Most cultivars are bearing flowers in shades of purple and blue. It is usually grown in beds, borders, containers, ground covers and indoor plant. However, its use as cut flowers cannot be denied. Additionally, it attracts butterflies.

Light and shade are very important environmental factors that affect Plant form, flowering, leaf size, and leaf greenness as well as plants physiology and biochemistry in both herbaceous (Jeong et al., 2009) and woody species (Hampson et al., 1996). Many research works have shown that light plays key role in changing the traits of plants (Riis et al., 2012, Lee et al., 2013, Adam and Cavaleri, 2014, Kuehne et al., 2014 and Lavinsky et al., 2014).
Phenotypic response to light can vary within a species, suggesting that selection may allow for development of cultivars with enhanced shade tolerance (Kitajima et al., 2006). Devkota and Kumar (2010) submitted Centella asiatic $a$ plant to four different shading levels: $0 \%$ (full sun), 30, 50 and $70 \%$ shading. They found that the highest plant biomass and root system resulted from submitted plants to $30 \%$ shading and full sun, respectively. Stanton et al. (2010) evaluated plants of Spiraea alba (meadowsweet) and Spiraea tomentosa (hardhack) under six different light treatments: full sun, morning full sun, afternoon full sun, and $40 \%, 60 \%$, and $80 \%$ shade. They reported that growth, flowering, and canopy density were greater in full sun and $40 \%$ shade and least in $80 \%$ shade. Both species responded to shade with increased individual leaf area. Plants grown in morning or afternoon shade were shorter and smaller and had fewer inflorescences than did the full-sun plants. Kwon and Woo (2016) 
reported that grown plants under enhanced light have increased palisade parenchyma, thicker leaf, higher biomass, increased photosynthesis, lower contents of chlorophyll, carotenoids and nitrogen.

Potassium is one of the most important elements in plant nutrition as a macro essential element for assimilate and improve growth and yield (Marshner, 1995). Potassium in elemental form is generally required to energize more than 50 different enzymes. The main source of $\mathrm{K}$ for plant comes from mineral and organic- K sources. In plants, the function of $\mathrm{K}$ has several roles such as enzyme activation, stimulation of assimilation and transport of assimilates. Also, Hart and Quick (1969) found that $\mathrm{K}$ promotes translocation of newly synthesized to different rated.

Habib and Zaghloul (2012) found that fertilizing Chrysanthemum frutescence plants with potassium sulphate at $3.0 \mathrm{~g} /$ pot showed positive effect on number of inflorescences / plant, fresh and dry weight of shoots and total fresh and dry weight of shoots + roots, chlorophylls $\mathrm{a}$ and $\mathrm{b}$ content in fresh leaves as well as total carbohydrates, nitrogen, phosphorus and potassium contents. Muhammad Shah et al (2014) evaluated the effect of three levels of potassium sulphate $\left(0,10,20 \mathrm{~g} \mathrm{~m}^{-2}\right.$ on growth and flowering of Zinnia elegans plant. They found that application $\mathrm{K}$ at the rate of $20 \mathrm{~g} \mathrm{~m}^{-2}$ showed encouraging impact on flowers number per plant, flower diameter, flower fresh and dry weight, plant height, number of primary and secondary shoots per plant, number of leaves per plant, leaf area and number of roots as well as roots length.

Potassium citrate is potassium salt of citric acid which considered one of the most important organic acids in the respiratory pathways into plant cell. Citric acid plays an important role in plant metabolism, where it act as non-enzymatic antioxidant in chelating free radicals and protecting plant from injury that could result in prolonging the shelf life of plant cells and improving growth characters (Sadak and Orabi, 2015). Borowski and Michałek (2009) sprayed spinach plants with $1 \%$ solution of different sources of potassium $(\mathrm{KCl}$, $\mathrm{KNO} 3$, K2SO4 and $\mathrm{C} 6 \mathrm{H} 5 \mathrm{~K} 3 \mathrm{O} 7 \cdot \mathrm{H} 2 \mathrm{O}$ ). They found that fertilized plants with $\mathrm{KNO} 3$ had the highest content of potassium in leaves, and those fertilized with $\mathrm{K} 2 \mathrm{SO} 4$, $\mathrm{C} 6 \mathrm{H} 5 \mathrm{~K} 3 \mathrm{O} 7 \mathrm{H} 2 \mathrm{O}$ and $\mathrm{KCl}$ had only slightly lower potassium content. The application of potassium increased chlorophyll, Carotenoids and nitrates leaf contents as well as

Egypt. J. Hort. Vol. 44, No. 1 (2017) leaf yield. Taha et al (2014) evaluated the effect of different sources of potassium i.e. feldspar (4800 and $7200 \mathrm{~g} /$ tree), potassium carbonate ( 850 and $1275 \mathrm{~g} /$ tree), potassium citrate (1263 and $1895 \mathrm{~g} /$ tree) and mono potassium phosphate (1333 and $2000 \mathrm{~g} /$ tree) on leaf area and leaf mineral content of Zebda Mango trees. Results indicated that all different potassium forms applications had a positive effect on leaf area and mineral content. Potassium citrate at the rate of $1263 \mathrm{~g} /$ tree and mono potassium phosphate at $2000 \mathrm{~g} /$ tree were the best treatments to increase leaf area and improve leaf mineral content. Ibrahim et al (2015) found that foliar application of potassium citrate $(\mathrm{KC})$ at $2000 \mathrm{ppm}$ and folic acid (FA) at $100 \mu \mathrm{g} . \mathrm{L}-1$ individually and in combination significantly improved most studied growth parameters in potato plants including plant length, leaf area, haulm dry weight and chlorophyll reading compared to the controls.

Humic substances were classified into three general categories like humic acid, fulvic acid and Humin (Solange and Rezende, 2008). Humic acid is commercial product contains many functional groups situated at the carbon chain. They could be acidic (e.g. carboxylic acid and phenol), alkaline (e.g. amine, imines) or neutral groups (e.g. alcohol, aldehyde, ketone, ether, ester and amide) which improve plant growth. Humic acid compounds play an important role in improvement of physical, chemical and biological conditions of the soil as well as its role in activation of plant growth (Gomma \& Youssef, 2008, El-Razek et al., 2012 and Ahmed et al., 2013). Potassium humate is a highly concentrated form and inexpensive soluble salts of humus in the naturally occurring lignite which is the brown coal that accompanies coal deposits (Fong et al., 2007). Gulser et al. (2010) found that Application of humic acid and calcium nitrate significantly affected seedling pepper growth by increasing fresh and dry leaf weight, fresh and dry root weight, stem diameter, root length and shoot length. Hashish et al. (2015) evaluated the effect of foliar spray with potassium humate $(0.0,0.5$, $1.0,1.5,2.0,2.5$ and $3.0 \% \mathrm{~K}$-humate) on growth and some chemical constituents of Jatropha curcas L. plants. Most criteria of vegetative growth expressed plant height, stem diameter, leaves number/plant, leaf area, root length, fresh and dry weight of leaves, stems and roots as well as chemical composition ,chlorophyll $\mathrm{a}, \mathrm{b}$ and carotenoids and total carbohydrates \%, increased by increasing K-humate concentrations 
compared with control plants. El-Shayeb et al. (2015) investigated the possibility of reducing the need for NPK chemical fertilization as well as improving plant productivity of Salvia officinalis L. plants by using humic acid as an alternative. The plants received $75 \% \mathrm{NPK}+10 \mathrm{ml} / \mathrm{L}$ humic acid gave higher values of vegetative characters and chemical composition.

Plant biostimulators are relatively new products which are used to obtain high and best quality yield, especially under unfavourable, for plant growth, environmental conditions. It play an important role in activating several metabolic procedures such as respiration, photosynthesis, nucleic acid synthesis and ion uptake and when applied in small quantities, improve the plant growth and development (Rafiee et al., 2016). Positive effects of plant biostimulators application have yielded extraordinary results on rosemary (Jelacic et al., 2007), peppermint (Kołodziej, 2008) and spinach (Smolen and Sady, 2010). Asahi SL, a Japanese product, internationally known as Atonik or Chaperone, is listed among most frequently used biostimulators. The protective role of Atonik against stresses was reported by Wrochna et al. (2008) for ornamental amaranth plants grown under salinity stress. Przybysz et al (2010) reported that foliar application of Asahi SL $(0.1 \% \mathrm{v} / \mathrm{v})$ on Arabidopsis thaliana L. plants positively affects plant height, leaf area, numbers of inflorescences, fresh and dry weights of plants and chlorophyll content. The objective of this study was to evaluate the effect of biostimulator Asahi SL (Atonik) and different sources of potassium either individually or in combination with atonik on growth parameters and chemical composition of Salvia farinacea plants under open field and partial shade conditions.

\section{Materials and Methods}

Two pot experiments were carried out at the Experimental Nursery of the Ornamental
Horticulture Department, Faculty of Agriculture, Cairo University, Giza $\left(30^{\circ} 01\right.$ ' 39.36 'N latitude and $31^{\circ} 12^{\prime} 36.50^{\prime \prime}$ E Longitude) during 2014/15 and $2015 / 16$ seasons to study the effect of biostimulator Asahi SL (Atonik) and different sources of potassium on growth, flowering and chemical constituents of Salvia farinacea plants (Var. Victoria blue) that were grown here as an annual plant. Chemical and physical characteristics of Atonik are listed in Table (1). The soil textural class of the experimental soil is loamy clay with, $\mathrm{pH}$ (8.0 and 7.82), EC (1.42 and $1.52 \mathrm{ds} / \mathrm{m})$, organic matter (1.45 and 1.60\%), available N (25.12 and 28.20 ppm), available P (16.50 and $18.65 \mathrm{ppm})$ and available $\mathrm{K}$ (150 and $165 \mathrm{ppm}$ ) in the first and second seasons, respectively. The first experiment was conducted under open field conditions, while the second one was conducted under partial shade conditions in seiran house (50\% shade). Blue Sage seeds were sown in plastic pots $10 \mathrm{~cm}$ diameter in glasshouse ( 3 seeds $/ p o t)$ on September $15^{\text {th }}$ in both seasons. The seedlings at 10 to $12 \mathrm{~cm}$ height were transplanted into $30 \mathrm{~cm}$ diameter plastic pots on November $15^{\text {th }}$ in both seasons.

\section{Experimental treatments and designs}

Each experiment received the following treatments:

- Control treatment (spraying plants with distilled water)

- $\quad$ Spraying plants with biostimulator Asahi SL( Atonik) at $2 \mathrm{~cm}^{3} / \mathrm{L}$

- Spraying plants with potassium humate at $3 \mathrm{~g} / \mathrm{L}$

- Spraying plants with potassium citrate $\left(\mathrm{C}_{6} \mathrm{H}_{5} \mathrm{~K}_{3} \mathrm{O}_{7} \cdot \mathrm{H}_{2} \mathrm{O}\right)$ at $2 \mathrm{~g} / \mathrm{L}$

- Spraying plants with potassium sulphate $\left(\mathrm{K}_{2} \mathrm{SO}_{4}\right)$ at $2 \mathrm{~g} / \mathrm{L}$

- Spraying plants with Atonik $(2 \mathrm{~cm} / \mathrm{L})+$ potassium humate $(3 \mathrm{~g} / \mathrm{L})$

TABLE 1. Chemical composition and physical properties of atonik plant stimulant.

\begin{tabular}{l|c}
\hline \multicolumn{2}{c}{ Chemical composition } \\
\hline 5 Nitroguaiacol Sodium & $17 \%$ \\
O-Nitrophenolate Sodium & $33 \%$ \\
P- Nitrophenolate Sodium & \multicolumn{1}{c}{ physical properties } \\
\hline \multicolumn{3}{c}{} & $50 \%$ \\
\hline Appearance & Reddish-brown \\
Melting point & $105-106^{\circ} \mathrm{C}$ \\
Solubility & Easily soluble in water and solvents \\
Stability & Stable under normal conditions \\
\hline
\end{tabular}


- Spraying plants with Atonik $(2 \mathrm{~cm} / \mathrm{L})+$ potassium citrate $(2 \mathrm{~g} / \mathrm{L})$

- Spraying plants with Atonik $(2 \mathrm{~cm} / \mathrm{L})+$ potassium sulphate $(2 \mathrm{~g} / \mathrm{L})$

Plants were sprayed 4 times, the first one was applied one month after transplanting the seedlings, then plants received these treatments as foliar application monthly until $15^{\text {th }}$ March. The experimental treatments either in open field or under seiran house were laid out in a randomized complete block design with three replications. Each replicate represented by 5 pots with one plant per pot.

\section{Studied characters \\ By mid-May data on all plants of each replicate were measured for the following characters:}

- Growth traits viz., plant height, stem diameter, branches number/plant, leaf area (using leaf area meter), Leaves number/ plant, roots number/plant, inflorescences number/plant, fresh and dry weights of leaves, stems, roots and inflorescences per plant.

- Chemical determinations viz., chlorophyll $\mathrm{a}, \mathrm{b}$ and carotenoids that were determined in $0.5 \mathrm{~g}$ fresh samples of leaves according to Saric et al. (1967). Total carbohydrates content was determined in homogenized samples $(0.2 \mathrm{~g})$ from dried leaves according to Dubois et al. (1956), nitrogen content was determined by the modified microKjeldahl method as described by A. O. A. C. (1990), phosphorus content was determined according to the method of Jackson (1967). Potassium was determined using Model SP 1900 atomic absorption spectrophotometer with a boiling air-acetylene burner and recorded read out.

\section{Statistical analysis}

Data recorded on growth traits were subjected to normal statistical analysis according to Steel et al. (1997) using MSTAT-C computer package (Freed et al., 1989). Treatment mean comparisons were performed using least significant difference (LSD) at 5\% level of probability. After homogeneity test, combined analysis was done to compare between open field and partial shade environments as well as testing the significance of interaction between treatments and environments.

\section{$\underline{\text { Results and Discussion }}$}

Data presented in Table 2 revealed that foliar application of biostimulator atonik and different sources of potassium either individually or in combination with atonik had a significant positive effect on plant height, stem diameter and leaf area of sage plants in both environments (full sun and partial shade conditions) and across environments in the two growing seasons. Under open field conditions, spraying plants with potassium humate gave the tallest plants (46.00 and 40.36 $\mathrm{cm})$ in the first and second season, respectively, while the highest values for stem diameter $(8.82$ and $8.50 \mathrm{~mm}$ ) and individual leaf area $(15.85$ and $15.04 \mathrm{~cm}^{2}$ ) resulted from spraying plants with potassium sulphate + atonik in the first and second season, respectively. Under seiran house, plants sprayed with potassium sulphate + atonik were superior for plant height (66.33 and 81.67 $\mathrm{cm})$ and leaf area $\left(16.20\right.$ and $\left.17.99 \mathrm{~cm}^{2}\right)$ in the first and second season, respectively, while the thicker stems $(6.84$ and $5.33 \mathrm{~mm})$ resulted from spraying plants with potassium citrate in the first and second season, respectively. Interaction between fertilization treatments and growing conditions (environments) was significant for plant height, stem diameter and leaf area in both seasons. The highest values of plant height and leaf area were obtained by spraying plants with potassium sulphate + atonik under partial shade environment, while the same treatment gave the highest value of stem diameter under open field condition. The positive effect of atonik and different sources of potassium on plant growth criteria such as plant height, stem diameter and leaf area was reported by Przybysz et al. (2010), Taha et al. (2014), Muhammad Shah et al. (2014) and Hashish et al (2015). With all fertilization treatments, plants grown under partial shade conditions were superior for plant height and individual leaf area, while those grown under open field conditions were superior for stem diameter. Therefore, the mean values for plant height and leaf area under shading environment was significantly higher than those under full sun environment, while the mean value for stem diameter under full sun environment were significantly higher than that under shading environment in the two growing seasons. The results on the effect of shading on leaf area agreed with that reported by Stanton et al. (2010). Growing plants under variable light intensity and temperature leads to morphological changes (Riis et al., 2012). 
TABLE 2. Effect of atonik and potassium on growth of Salvia farinacea plant under sun and partial shading conditions during 2014/15 and 2015/16 seasons.

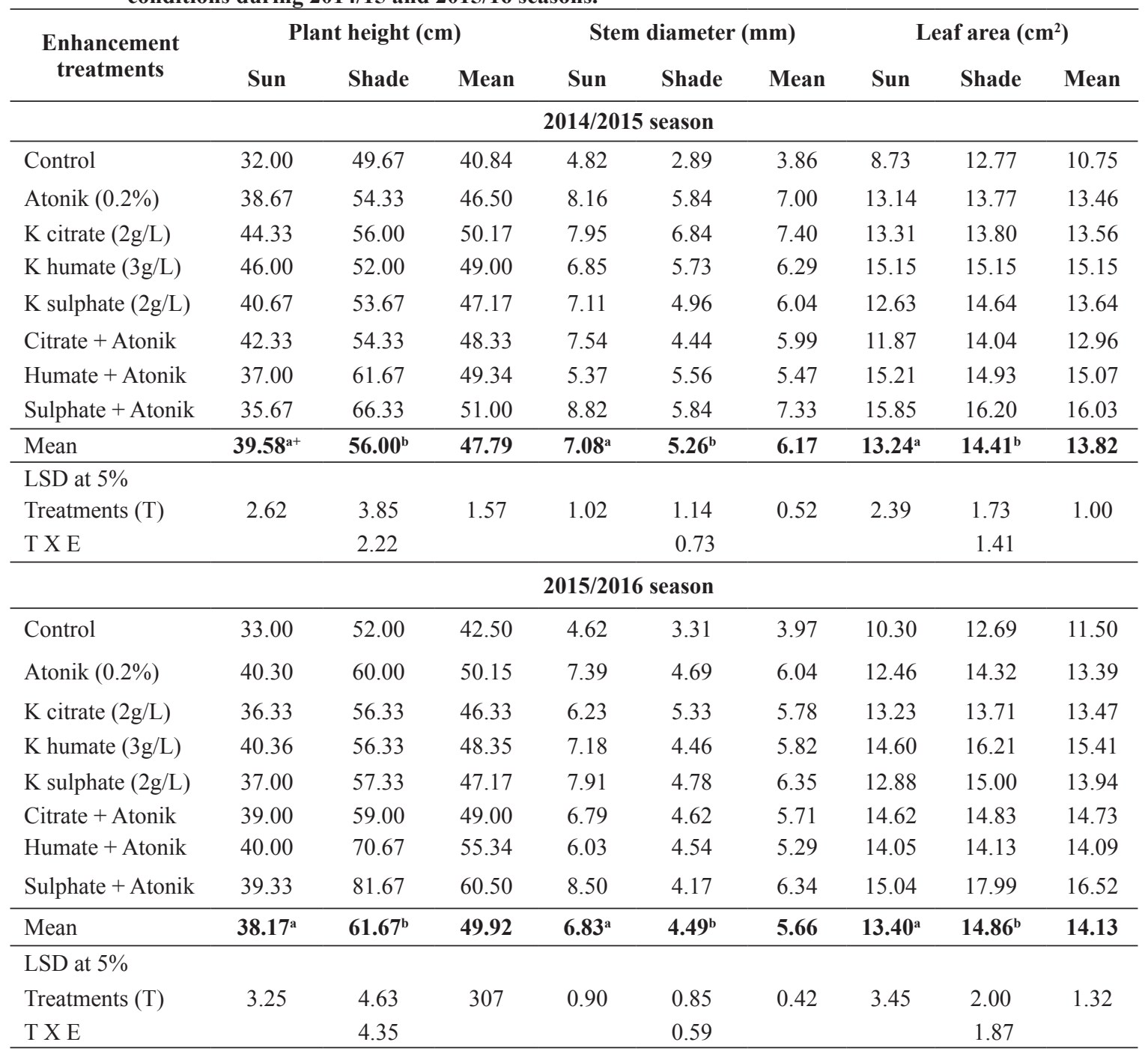

Data in Table 3 illustrate that the number of leaves, branches, roots and inflorescences per plant were positively significantly affected by foliar application of biostimulator atonik and different sources of potassium either individually or in combination with atonik in the positive direction. This was true under open field (full sun) and seiran house (50\% shade) conditions as well as across environments in both seasons. Under open field conditions, spraying the plants with potassium humate gave the highest number of leaves (409.33 and 396.67) and inflorescences (24.33 and 21.00) in the first and second season, respectively. The highest number of branches (24.00 and 24.67) resulted from spraying plants with potassium citrate in the first and second season, respectively. The highest number of roots fluctuated from 9.33 roots in the first season for the plants sprayed with atonik to 9.67 roots in the second season for the plants fertilized with potassium citrate + atonik. Under partial shading, plants sprayed with potassium citrate + atonik were superior for number of leaves $(230.00$ and 203.33), number of branches (14.00 and 13.00) and number of inflorescence (5.67 and 6.67) in the first and second season, respectively, while the highest number of roots (8.33 an 8.00) resulted from spraying plants with potassium humate + atonik in the first and second season, respectively. Interaction between fertilization treatments and growing conditions (environments) was significant for number of leaves, branches, roots and inflorescences per plant in both seasons. Foliar application of potassium humate for plants grown 
under full sun conditions gave the highest number of leaves and inflorescence in both seasons. The obtained results were in line with that reported by Muhammad Shah et al. (2014) and Hashish et al (2015). With all fertilization treatments, plants grown under open field conditions were superior for number of leaves, branches, roots and inflorescences in both seasons. The mean values for number of leaves, branches and inflorescence under full sun conditions were significantly higher than those grown under partial shading. The effect of shading on number of inflorescences agreed with that reported by Stanton et al. (2010).

Fresh and dry weights of leaves and stems per plant (Table 4) were significantly increased by foliar application of biostimulator atonik and different sources of potassium alone or in combination with atonik under both environments and across environments in the two seasons. Under the open field conditions, spraying the plants with potassium humate gave the highest biomass of fresh leaves (30.70 and $29.08 \mathrm{~g})$, dry leaves $(7.28$ and $7.15 \mathrm{~g})$, fresh stems $(24.30$ and $25.06 \mathrm{~g})$ and dry stems (7.65 and $7.99 \mathrm{~g})$ in the first and second season, respectively. Under partial shading, sprayed plants with potassium citrate + atonik gave the highest weight of fresh leaves (16.62 and $14.85 \mathrm{~g}$ ) and dry leaves (3.68 and 3.12 $\mathrm{g})$, while the highest weight of fresh stems (13.81 and $14.51 \mathrm{~g}$ ) and dry stems (4.20 and $4.42 \mathrm{~g}$ ) resulted from spraying the plants with potassium sulphate + atonik in the first and second season, respectively. Fresh and dry weights of leaves and stems per plant were significantly affected by the interaction between fertilization treatments and growing conditions (environments) in both seasons. Foliar application of potassium humate for plants grown under full sun conditions gave the highest fresh and dried yields of leaves and stems in both seasons. The positive effect of atonik and different sources of potassium on biomass yield was reported by Przybysz et al. (2010), Habib and Zaghloul (2012), Ibrahim et al. (2015)

TABLE 3. Effect of atonik and potassium on growth and flowering of Salvia farinacea plant under sun and partial shading conditions during 2014/15 and 2015/16 seasons.

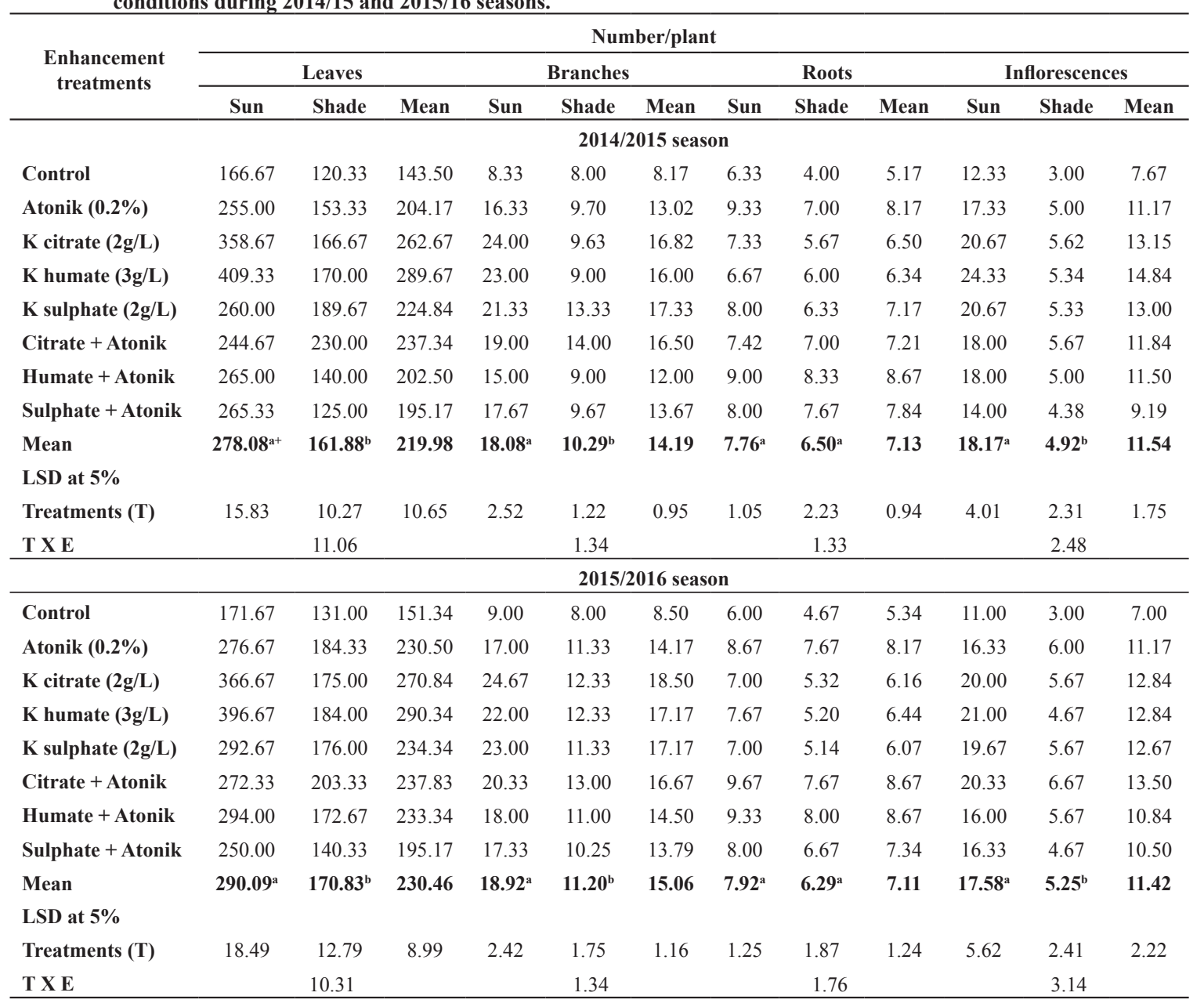

Egypt. J. Hort. Vol. 44, No. 1 (2017) 
and Hashish et al (2015). The obtained results in Table 4 cleared that biomass yield for plants grown under full sun conditions was higher than of those grown under partial shading conditions. This was true for each fertilization treatment in both seasons. Over fertilization treatments, the mean values of fresh and dry weights of leaves and stems for plants grown under full sun conditions were significantly higher than that for plants grown under partial shading in the two seasons. This result was in line with that reported by Devkota and Kumar (2010) and Kwon and Woo (2016).

Foliar application of biostimulator atonik and different sources of potassium alone or in combination with atonik affected positively and significantly on Fresh and dry weights of roots and inflorescences of Salvia farinacea plants (Table 5) under full sun and partial shading conditions and across environments in both seasons. Under full sun conditions, the fresh and dry weight of roots ranged between $7.01 \mathrm{~g}$ and $1.95 \mathrm{~g}$ for plants sprayed with distilled water (control) to $11.23 \mathrm{~g}$ and $3.75 \mathrm{~g}$, respectively for plants sprayed with potassium sulphate + atonik in the first season, corresponding to 7.28 and $2.15 \mathrm{~g}$ for control plants to 11.41 and $3.76 \mathrm{~g}$ for plants sprayed with potassium sulphate + atonik in the second season. Under partial shading, fresh and dry weight of roots ranged between $5.20 \mathrm{~g}$ and $1.32 \mathrm{~g}$ for the plants sprayed with distilled water (control) to $6.72 \mathrm{~g}$ and $2.05 \mathrm{~g}$, respectively for plants sprayed with atonik in the first season, corresponding to $5.13 \mathrm{~g}$ and $1.48 \mathrm{~g}$ for control plants to $7.47 \mathrm{~g}$ and $2.38 \mathrm{~g}$ for the plants sprayed with atonik in the second season. Sage plants grown under full sun conditions gave the highest biomass of fresh and dry inflorescences when sprayed with potassium citrate + atonik in the first (15.97 and $2.70 \mathrm{~g}$ ) and in the second season (16.24 and $2.85 \mathrm{~g}$ ), respectively. Also, foliar application of potassium citrate + biostimulator atonik to sage plants grown under partial shading resulted in the highest biomass of fresh and dry inflorescences in the first (10.21 and $1.72 \mathrm{~g}$ ) and in the second seasons (12.20 and $2.00 \mathrm{~g})$, respectively. Fresh and dry weights of roots and inflorescences were

TABLE 4. Effect of atonik and potassium on growth of Salvia farinacea plant under sun and partial shading conditions during 2014/15 and 2015/16 seasons.

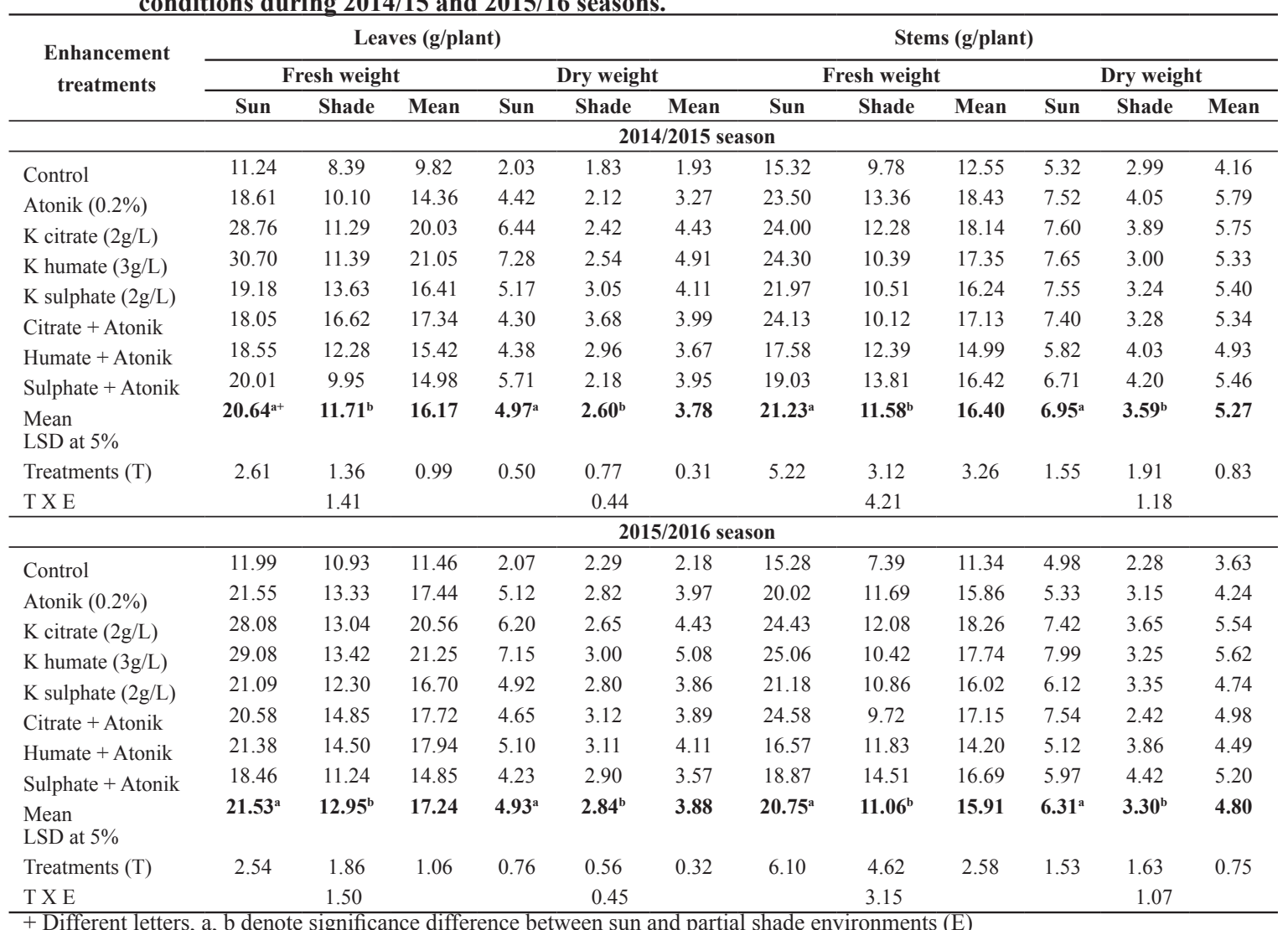


significantly affected by the interaction between fertilization treatments and growing conditions (environments) in both seasons. Foliar application of potassium citrate + atonik for plants grown under full sun conditions gave the highest fresh and dried yields of inflorescences in both seasons, while spraying plants with potassium sulphate + atonik gave the highest fresh and dried weights of roots under open field conditions in both seasons. These results were in line with that reported by Devkota and Kumar (2010), Przybysz et al. (2010) and Ibrahim et al. (2015). The obtained results in Table 5 cleared that fresh and dry weight of roots and inflorescences for plants grown under full sun conditions was higher than of those grown under partial shading. This was true for each fertilization treatment in both seasons. Over fertilization treatments, the mean values of fresh and dry weights of roots and inflorescences of plants grown under full sun conditions were significantly higher than the mean values for plants grown under partial shading in the two seasons. This result agreed with that reported by Stanton et al. (2010) and Kwon and Woo (2016).

Data presented in Table 6 revealed that leaves pigments content in terms of chlorophyll $\mathrm{a}$, chlorophyll $\mathrm{b}$ and carotenoids was positively and significantly affected by biostimulator atonik and different sources of potassium alone or in combination with atonik under both environments and across environments in both seasons. Under open field conditions, Chlorophyll a content varied from $1.58 \mathrm{mg} / \mathrm{g}$ for plants sprayed with distilled water (control) to $2.32 \mathrm{mg} / \mathrm{g}$ for plants sprayed with potassium humate in the first season, corresponding to $1.36 \mathrm{mg} / \mathrm{g}$ for control plants to $2.39 \mathrm{mg} / \mathrm{g}$ for plants sprayed with potassium citrate + atonik in the second season. Chlorophyll b content varied from $0.92 \mathrm{mg} / \mathrm{g}$ for control plants to $1.97 \mathrm{mg} / \mathrm{g}$ for plants sprayed with potassium humate + atonik in the first season,

TABLE 5. Effect of atonik and potassium on growth and flowering parameters of Salvia farinacea plant under sun and partial shading conditions during 2014/15 and 2015/16 seasons.

\begin{tabular}{|c|c|c|c|c|c|c|c|c|c|c|c|c|}
\hline \multirow{3}{*}{$\begin{array}{c}\text { Enhancement } \\
\text { treatments }\end{array}$} & \multicolumn{6}{|c|}{ Roots (g/plant) } & \multicolumn{6}{|c|}{ Inflorescences (g/plant) } \\
\hline & \multicolumn{3}{|l|}{$\begin{array}{c}\text { Fresh } \\
\text { weight }\end{array}$} & \multicolumn{3}{|c|}{ Dry weight } & \multicolumn{3}{|c|}{ Fresh weight } & \multicolumn{3}{|c|}{ Dry weight } \\
\hline & Sun & Shade & Mean & Sun & Shade & Mean & Sun & Shade & Mean & Sun & Shade & Mean \\
\hline & \multicolumn{11}{|c|}{$2014 / 2015$ season } & \\
\hline Control & 7.01 & 5.20 & 6.11 & 1.95 & 1.32 & 1.64 & 7.64 & 6.17 & 6.91 & 1.15 & 0.92 & 1.04 \\
\hline Atonik (0.2\%) & 10.07 & 6.72 & 8.40 & 3.15 & 2.05 & 2.60 & 10.25 & 7.31 & 8.78 & 1.81 & 1.11 & 1.46 \\
\hline$K$ citrate $(2 \mathrm{~g} / \mathrm{L})$ & 8.38 & 6.39 & 7.39 & 2.54 & 1.82 & 2.18 & 12.62 & 7.95 & 10.29 & 2.25 & 1.25 & 1.75 \\
\hline K humate $(3 g / L)$ & 8.24 & 6.20 & 7.22 & 2.44 & 1.78 & 2.11 & 15.15 & 9.72 & 12.44 & 2.65 & 1.55 & 2.10 \\
\hline K sulphate $(2 \mathrm{~g} / \mathrm{L})$ & 10.17 & 5.27 & 7.72 & 3.25 & 1.45 & 2.35 & 14.82 & 8.76 & 11.79 & 2.56 & 1.42 & 1.99 \\
\hline Citrate + Atonik & 8.70 & 6.03 & 7.37 & 2.85 & 1.88 & 2.37 & 15.97 & 10.21 & 13.09 & 2.70 & 1.72 & 2.21 \\
\hline Humate + Atonik & 8.74 & 6.37 & 7.56 & 2.75 & 1.91 & 2.33 & 13.37 & 8.06 & 10.72 & 2.36 & 1.38 & 1.87 \\
\hline Sulphate + Atonik & 11.23 & 6.38 & 8.81 & 3.75 & 1.93 & 2.84 & 15.14 & 9.65 & 12.40 & 2.63 & 1.54 & 2.09 \\
\hline Mean & $9.07^{\mathrm{a}+}$ & $6.07^{b}$ & 7.57 & $2.84^{\mathrm{a}}$ & $1.77^{\mathrm{b}}$ & 2.30 & $13.12^{\mathrm{a}}$ & $8.48^{\mathrm{b}}$ & 10.80 & $2.26^{\mathrm{a}}$ & $1.36^{\mathrm{b}}$ & 1.81 \\
\hline \multicolumn{13}{|l|}{ LSD at 5\% } \\
\hline Treatments (T) & 1.27 & 1.42 & 0.66 & 0.82 & 0.58 & 0.50 & 1.54 & 0.58 & 1.28 & 0.22 & 0.11 & 0.15 \\
\hline T X E & & 0.94 & & & 0.71 & & & 2.49 & & & 0.18 & \\
\hline & \multicolumn{11}{|c|}{$2015 / 2016$ season } & \\
\hline Control & 7.28 & 5.13 & 6.21 & 2.15 & 1.48 & 1.82 & 8.73 & 6.98 & 7.86 & 1.34 & 1.02 & 1.18 \\
\hline Atonik (0.2\%) & 10.00 & 7.47 & 8.74 & 3.28 & 2.38 & 2.83 & 11.46 & 8.81 & 10.14 & 1.88 & 1.31 & 1.60 \\
\hline$K$ citrate $(2 g / L)$ & 8.09 & 5.85 & 6.97 & 2.59 & 1.71 & 2.15 & 13.28 & 10.27 & 11.78 & 2.24 & 1.58 & 1.91 \\
\hline$K$ humate $(3 g / L)$ & 7.62 & 5.67 & 6.65 & 2.50 & 1.73 & 2.12 & 15.40 & 11.82 & 13.61 & 2.32 & 1.83 & 2.08 \\
\hline K sulphate $(2 \mathrm{~g} / \mathrm{L})$ & 8.72 & 5.42 & 7.07 & 2.72 & 1.75 & 2.24 & 15.37 & 11.50 & 13.44 & 2.65 & 1.89 & 2.27 \\
\hline Citrate + Atonik & 10.87 & 5.68 & 8.28 & 3.55 & 1.82 & 2.69 & 16.24 & 12.20 & 14.22 & 2.85 & 2.00 & 2.43 \\
\hline Humate + Atonik & 9.78 & 5.48 & 7.63 & 3.11 & 1.73 & 2.42 & 14.61 & 10.66 & 12.64 & 2.25 & 1.77 & 2.01 \\
\hline Sulphate + Atonik & 11.41 & 5.52 & 8.47 & & 1.88 & 2.82 & 15.84 & 11.95 & 13.90 & 2.67 & 1.90 & 2.29 \\
\hline Mean & $9.22^{\mathrm{a}}$ & $5.78^{\mathrm{b}}$ & 7.50 & $2.96^{\mathrm{a}}$ & $1.81^{b}$ & 2.38 & $13.87^{a}$ & $10.52^{\mathrm{b}}$ & 12.20 & $2.28^{\mathrm{a}}$ & $1.66^{\mathrm{b}}$ & 1.97 \\
\hline \multicolumn{13}{|l|}{ LSD at $5 \%$} \\
\hline Treatments (T) & 2.93 & 2.03 & 1.20 & 0.95 & 0.63 & 0.78 & 1.68 & 0.62 & 1.30 & 0.25 & 0.13 & 0.16 \\
\hline $\mathbf{T} \mathbf{X} \mathbf{E}$ & & 1.70 & & & 1.10 & & & 2.22 & & & 0.20 & \\
\hline
\end{tabular}

+ Different letters, $\mathrm{a}, \mathrm{b}$ denote significance difference between sun and partial shade environments $(\mathrm{E})$

Egypt. J. Hort. Vol. 44, No. 1 (2017) 
corresponding to $0.82 \mathrm{mg} / \mathrm{g}$ for control plants to $1.47 \mathrm{mg} / \mathrm{g}$ for plants sprayed with potassium humate in the second season. Carotenoids content varied from $0.23 \mathrm{mg} / \mathrm{g}$ for control plants to $0.49 \mathrm{mg} / \mathrm{g}$ for those sprayed with atonik in the first season, corresponding to $0.31 \mathrm{mg} / \mathrm{g}$ for control plants to $0.46 \mathrm{mg} / \mathrm{g}$ for plants sprayed with potassium humate + atonik in the second season. Under partial shading, spraying the plants with potassium sulphate + atonik gave the highest content of chlorophyll a (1.72 and $1.39 \mathrm{mg} / \mathrm{g})$ and chlorophyll b ( 1.18 and $0.91 \mathrm{mg} / \mathrm{g}$ ) in the first and second season, respectively. The highest content of carotenoids fluctuated among $0.30 \mathrm{mg} / \mathrm{g}$ in the first season for plants fertilized with potassium citrate and $0.16 \mathrm{mg} / \mathrm{g}$ in the second season for the plants fertilized with potassium citrate + atonik. Chlorophyll and carotenoids contents in leaves were significantly affected by the interaction between fertilization treatments and growing conditions (environments) in both seasons. The positive effect of atonik and different sources of potassium on chlorophyll and carotenoids contents was reported by Borowski and Michałek (2009), Przybysz et al. (2010), Habib and Zaghloul (2012), Hashish et al (2015) and Ibrahim et al. (2015). The obtained results in Table (6) cleared that over fertilization treatments, the mean values of chlorophyll a, chlorophyll b and carotenoids contents in the leaves of plants grown under full sun environment were significantly higher than mean values of plants grown under partial shading in the two seasons. High contents of chlorophyll may be enhanced photosynthesis in plants grown under full sun conditions and therefore increased biomass yield of full sun sage plants.

Data presented in Table 7 indicated that the mean values of total carbohydrates, nitrogen, phosphorus and potassium contents in the dry leaves of sage plants increased by foliar application of biostimulator atonik and

TABLE 6. Effect of atonik and potassium on chlorophyll and carotenoids contents under sun and partial shading conditions during 2014 and 2015 seasons.

\begin{tabular}{|c|c|c|c|c|c|c|c|c|c|}
\hline \multirow{2}{*}{ Enhancement treatments } & \multicolumn{3}{|c|}{ Chl. a (mg/g) } & \multicolumn{3}{|c|}{ Chl. b (mg/g) } & \multicolumn{3}{|c|}{ Carotenoids (mg/g) } \\
\hline & Sun & Shade & Mean & Sun & Shade & Mean & Sun & Shade & Mean \\
\hline \multicolumn{10}{|c|}{$2014 / 2015$ season } \\
\hline Control & 1.58 & 0.77 & 1.18 & 0.92 & 0.68 & 0.80 & 0.23 & 0.10 & 0.17 \\
\hline Atonik $(0.2 \%)$ & 1.93 & 0.97 & 1.45 & 1.14 & 0.90 & 1.02 & 0.49 & 0.23 & 0.36 \\
\hline$K$ citrate $(2 g / L)$ & 2.03 & 1.10 & 1.57 & 1.55 & 0.94 & 1.25 & 0.38 & 0.30 & 0.34 \\
\hline K humate $(3 g / L)$ & 2.32 & 1.20 & 1.76 & 1.62 & 1.00 & 1.31 & 0.26 & 0.13 & 0.20 \\
\hline K sulphate $(2 \mathrm{~g} / \mathrm{L})$ & 2.08 & 1.29 & 1.69 & 1.52 & 1.06 & 1.29 & 0.42 & 0.11 & 0.27 \\
\hline Citrate + Atonik & 2.21 & 1.49 & 1.85 & 1.88 & 0.97 & 1.43 & 0.28 & 0.12 & 0.20 \\
\hline Humate + Atonik & 2.16 & 1.43 & 1.80 & 1.97 & 1.10 & 1.54 & 0.28 & 0.11 & 0.20 \\
\hline Sulphate + Atonik & 2.22 & 1.72 & 1.97 & 1.56 & 1.18 & 1.37 & 0.35 & 0.14 & 0.25 \\
\hline Mean & $2.07^{a^{+}}$ & $1.25^{b}$ & 1.66 & $1.52^{\mathrm{a}}$ & $0.98^{b}$ & 1.25 & $0.34^{\mathrm{a}}$ & $0.16^{b}$ & 0.25 \\
\hline \multicolumn{10}{|l|}{ LSD at $5 \%$} \\
\hline Treatments (T) & 0.11 & 0.08 & 0.07 & 0.07 & 0.05 & 0.06 & 0.03 & 0.02 & 0.03 \\
\hline \multirow[t]{2}{*}{$\mathbf{T} \mathbf{X} \mathbf{E}$} & & 0.09 & & & 0.08 & & & 0.04 & \\
\hline & \multicolumn{8}{|c|}{ 2015/2016 season } & \\
\hline Control & 1.36 & 1.10 & 1.23 & 0.82 & 0.53 & 0.68 & 0.31 & 0.11 & 0.21 \\
\hline Atonik (0.2\%) & 2.15 & 1.30 & 1.73 & 1.01 & 0.76 & 0.89 & 0.42 & 0.13 & 0.28 \\
\hline$K$ citrate $(2 g / L)$ & 2.24 & 1.35 & 1.80 & 1.33 & 0.59 & 0.96 & 0.40 & 0.14 & 0.27 \\
\hline K humate $(3 g / L)$ & 2.20 & 1.26 & 1.73 & 1.47 & 0.76 & 1.12 & 0.38 & 0.14 & 0.26 \\
\hline K sulphate $(2 \mathrm{~g} / \mathrm{L})$ & 2.38 & 1.21 & 1.80 & 1.28 & 0.89 & 1.09 & 0.40 & 0.14 & 0.27 \\
\hline Citrate + Atonik & 2.39 & 1.30 & 1.85 & 0.96 & 0.78 & 0.87 & 0.44 & 0.16 & 0.30 \\
\hline Humate + Atonik & 2.21 & 1.35 & 1.78 & 1.25 & 0.83 & 1.04 & 0.46 & 0.12 & 0.29 \\
\hline Sulphate + Atonik & 2.34 & 1.39 & 1.87 & 1.11 & 0.91 & 1.01 & 0.37 & 0.15 & 0.26 \\
\hline Mean & $2.16^{\mathrm{a}}$ & $1.28^{b}$ & 1.72 & $1.15^{\mathrm{a}}$ & $0.76^{b}$ & 0.96 & $0.40^{\mathrm{a}}$ & $0.14^{b}$ & 0.27 \\
\hline \multicolumn{10}{|l|}{ LSD at $5 \%$} \\
\hline Treatments (T) & 0.13 & 0.09 & 0.08 & 0.06 & 0.05 & 0.04 & 0.04 & 0.02 & 0.03 \\
\hline TX E & & 0.11 & & & 0.07 & & & 0.05 & \\
\hline
\end{tabular}

+ Different letters, a, b denote significance difference between sun and partial shade environments (E) 
different sources of potassium alone or in combination with atonik as compared to control treatment (distilled water) either under full sun or under partial shading in both seasons. Under full sun conditions, the highest value (28.65 and $28.50 \%$ ) of total carbohydrates was determined in plants sprayed with potassium sulphate + atonik, while under partial shading it was $(21.47$ and $23.13 \%)$ in the plants sprayed with potassium humate + atonik in the first and second seasons, respectively. Salvia farinacea plants showed slightly increasing uptake of nitrogen, phosphorus and potassium with foliar application of biostimulator atonik and different sources of potassium either alone or in combination with atonik as compared to control treatment. The obtained results cleared that over fertilization treatments, the mean values of total carbohydrates, nitrogen, phosphorus and potassium contents in the leaves of the plants grown under full sun conditions were higher than mean values of the plants grown under partial shading in both seasons. Increasing total carbohydrates, $\mathrm{N}, \mathrm{P}$ and $\mathrm{K}$ contents in plants fertilized with potassium was reported by Habib and Zaghloul (2012), Taha et al (2014) and Hashish et al (2015).

\section{Conclusion}

Foliar application of the biostimulator asahi (atonik) either alone or in combination with different sources of potassium had a great and positive effect on all growth and chemical parameters of Salvia farinacea plants under full sun and partial shading conditions. Therefore, atonik may be recommended for promoting growth parameters of Salvia farinacea L. plants. Salvia farinacea can survive well under partial shading conditions, but based on the measured growth parameters, they are best suited to full sun conditions.

Acknowledgements: This work was supported by the Faculty of Agriculture, Cairo University.

TABLE 7. Effect of atonik and potassium on total carbohydrates, nitrogen, phosphorus and potassium contents under sun

\begin{tabular}{|c|c|c|c|c|c|c|c|c|c|c|c|c|}
\hline $\begin{array}{c}\text { Enhancement } \\
\text { treatments }\end{array}$ & Sun & Shade & Mean & Sun & Shade & Mean & Sun & Shade & Mean & Sun & Shade & Mean \\
\hline Control & 21.08 & 17.28 & 19.18 & 1.50 & 1.20 & 1.35 & 0.16 & 0.14 & 0.15 & 2.80 & 2.40 & 2.60 \\
\hline$K$ humate $(3 g / L)$ & 25.64 & 17.98 & 21.81 & 2.20 & 2.00 & 2.10 & 0.29 & 0.18 & 0.24 & 4.20 & 3.60 & 3.90 \\
\hline K sulphate $(2 g / L)$ & 26.50 & 19.33 & 22.92 & 2.05 & 1.95 & 2.00 & 0.29 & 0.19 & 0.24 & 4.30 & 4.10 & 4.20 \\
\hline Citrate + Atonik & 23.57 & 20.34 & 21.96 & 2.80 & 2.60 & 2.70 & 0.24 & 0.21 & 0.23 & 3.80 & 3.50 & 3.65 \\
\hline \multirow[t]{2}{*}{ Mean } & 24.72 & 19.33 & 22.02 & 2.04 & 1.81 & 1.93 & 0.23 & 0.19 & 0.21 & 4.01 & 3.56 & 3.78 \\
\hline & \multicolumn{11}{|c|}{$2015 / 2016$ season } & \\
\hline Control & 19.48 & 15.58 & 17.53 & 1.60 & 1.20 & 1.40 & 0.25 & 0.20 & 0.23 & 3.50 & 3.00 & 3.25 \\
\hline Atonik $(0.2 \%)$ & 24.66 & 20.34 & 22.50 & 2.60 & 2.50 & 2.55 & 0.27 & 0.22 & 0.25 & 4.20 & 3.50 & 3.85 \\
\hline$K$ citrate $(2 g / L)$ & 21.47 & 17.24 & 19.36 & 2.20 & 2.40 & 2.30 & 0.28 & 0.24 & 0.26 & 4.30 & 3.60 & 3.95 \\
\hline K humate $(3 g / L)$ & 24.26 & 17.54 & 20.90 & 2.80 & 2.60 & 2.70 & 0.29 & 0.23 & 0.26 & 4.20 & 3.30 & 3.75 \\
\hline K sulphate $(2 g / L)$ & 26.57 & 19.51 & 23.04 & 2.20 & 2.50 & 2.35 & 0.25 & 0.22 & 0.24 & 4.50 & 3.40 & 3.95 \\
\hline
\end{tabular}

Egypt. J. Hort. Vol. 44, No. 1 (2017) 


\section{References}

Adam, P.C. and Cavaleri, M.A. (2014) Light drives vertical gradients of leaf morphology in a sugar maple (Acer saccharum) forest. Tree Physiol., 34 (2), 146-158.

Ahmed, A.H.H., Darwish, E., Hamoda, S.A.F. and Alobaidy, M.G. (2013) Effect of putrescine and humic acid on growth, yield and chemical composition of cotton plants grown under saline soil conditions. American-Eurasian J. Agri. Envi. Sci., 13, 479-497.

A.O.A.C. (1990) "Official Methods of Analysis", $15^{\text {th }}$ ed., Published by Association of Official Analytical Chemists, Washington, D.C., U. S. A. 684 p.

Borowski, E. and Michałek, S. (2009) The effect of foliar feeding of potassium salts and urea in spinach on gas exchange, leaf yield and quality. Acta Agrobotanica, 62 (1), 155-162.

Devkota, A. and Kumar, P. (2010) Effects of light levels on growth traits and yield of Centella asiatica. Middle-East J. Scientific Research, 5(4), 226-230.

Dubois, M., Gilles, K.A., Hamilton, J.K., Repers P.A. and Smith, F. (1956) Colorimetric method for determination of sugars and related substances. $J$. Analytical Chemistry, 28 (3), 350-356.

El-Razek, E.A., Abd-Allah, A.S.E. and Saleh, M.M.S. (2012) Yield and fruit quality of Florida Prince peach trees as affected by foliar and soil applications of humic acid. J. Applied Sci. Res., 8 (12), 5724-5729.

El-Shayeb, N.S.A., Abo El-Soud, I.H. and El-Shal, S.A. (2015) Effect of different levels of chemical fertilization and humic acid on Salvia officinalis L. plant. Egypt. J. of Appl. Sci., 30 (11), 2015 727758.

Fong, S.S., Seng, L. and Mat, H.B. (2007) Reuse of Nitric Acid in the Oxidative Pretreatment Step for Preparation of Humic Acids from Low Rank Coal of Mukah, Sarawak. J. Braz. Chem. Soc., 18, 41-46.

Freed, R.S.P., Einensmith, S., Gutez, S., Reicosky, D., Smail, V.W. and Wolberg, P. (1989) STAT-C analysis of agronomic research experiments. Michigan Univ. East Lansing, USA.

Gomaa, A.O. and Youssef, A.S.M. (2008) The effect of humic acid and biofertilization on caraway plant. 4th Scientific Conference Research, National Research Center, Cairo, Egypt 22-24 May, pp. 100-120.
Gulser, F., Sonmez, F. and Boysan, S. (2010) Effect of calcium nitrate and humic acid on pepper seedling growth under saline condition. Journal of Environmental Biology, 31 (5), 873-876, 2010.

Habib, A. M. and Zaghloul, S.M. (2012) Effect of Chemical, Organic and Bio-Fertilization on Growth and Flowering of Chrysanthemum frutescens Plants. Journal of Horticultural Science \& Ornamental Plants, 4 (2), 186-194.

Hampson, C.R., Azarenko, A.N. and Potter, J.R. (1996) Photosynthetic rate, flowering, and yield component alteration in hazelnut in response to different light environments. J. Amer. Soc. Hort. Sci., 121,1103-1111.

Hashish, K.H., El- Quesni, F.E.M. and Mazher, A. M. (2015) Influence of Potassium Humate on Growth and Chemical Constituents of Jatropha curcus L. Int. J. Chem. Tech. Res., 8 (9),279-283.

Hart, S.D. and Quick, J.S. (1969) Effect of potassium deficiency upon translocation of $\mathrm{C} 14$ in attached blades and entire plants of sugar cane. Plant Physiol., 44, 1461-1469.

Ibrahim, M.F.M., Abd El - Gawad, H. G. and Bondok, A. M. (2015) Physiological impacts of potassium citrate and folic acid on growth, yield and some viral diseases of potato plants. Middle East Journal of Agriculture, 4 (3), 577-589.

Jackson, M. L. (1967) Soil Chemical Analysis. Printice, Hall of India, pp. 144-197.

Jeong, K.Y., Pasian, C.C., McMahon, M. and Tay, D. (2009) Growth of six Begonia species under shading. Open Hort. J., 2, 22-28.

Jelacic S, Beatovic, D., Lakic, N. and Vujosevi, A. (2007) The effect of natural biostimulators and slow-is integrating fertilizers on the quality of rosemary seedlings (Rosmarinus officinalis L.). $J$. Agricultural Sciences, 52 (2), 85 -94.

Kitajima, K., Fox, A.M., Sato, T. and Nagamatsu, D. (2006) Cultivar selection prior to introduction may increase invasiveness: Evidence from Ardisia crenata. Biol. Invasions, 8, 1471-1482.

Kołodziej, B. (2008) The effect of drip irrigation and Asahi SL application on peppermint yield and quality. Herba Production, 54 (4),43-51. 
Kuehne C, Nosko, P., Horwath, T. and Bauhus, J. (2014) A comparative study of physiological and morphological seedling traits associated with shade tolerance in introduced red oak (Quercus rubra) and native hardwood tree species in southwestern Germany. Tree Physiol., 34 (2),184-193.

Kwon, M. Y and Woo, S. Y. (2016) Plants' responses to drought and shade environments. African $J$. Biotechnology, 15 (2), 29-31.

Lavinsky, A.O., Gomes, F.P., Mielke, M.S. and França, S. (2014) Photosynthetic acclimation in shade-developed leaves of Euterpe edulisMart (Arecaceae) after long-term exposure to high light. Photosynthetica, 52 (3), 351-357.

Lee, K.A., Lee, S.H. and Woo, S.Y. (2013) Rubisco activity and gene expression of tropical tree species under light stress. Afr. J. Biotechnol., 12 (20), 2764-2769.

Marshner, H. (1995) Mineral nutrition of higher plant. Academic.Press Publ. second edition, New York, USA, $559 \mathrm{p}$.

Muhammad Shah, S.N., Ali, A., Noor-ul-Amin, Mohib Shah and Abid Khan, (2014) Potassium influence on flowering and morphology of Zinnia Elegans. International Journal of Farming and Allied Sciences, 3 (4), 377-381.

Przybysz, A., Wrochna, M., Słowiński, A. and Gawrońska, H. (2010) Stimulatory effect of Asahi SL on selected plant species. Acta Sci. Pol., Hortorum Cultus, 9 (2), 53-64.

Rafiee, H., Naghdi Badi, H., Mehrafarin, A., Qaderi, A., Zarinpanjeh, N., Sekara, A. and Zand, E. (2016) Application of Plant Biostimulants as New Approach to Improve the Biological Responses of Medicinal Plants- A Critical Review. Journal of Medicinal Plants, 15 (59), 6-39.

Riis, T., Olesen, B., Clayton, J.S., Lambertini, C., Brix, H. and Sorrell, B.K. (2012) Growth and morphology in relation to temperature and light availability during the establishment of three invasive aquatic plant species. Aquatic Botany, 102,56-64.

Sadak, M.S. and Orabi, S.A. (2015) Improving thermo tolerance of wheat plant by foliar application of citric acid or oxalic acid. International Journal of ChemTech Research, 8 (1), 333-345.

Saric, M., Curic, R. and Cupina, T. (1967) Chlorophyll determination. Umverrit etU Noven Sadu Praktikum iz fiziologize Biljaka, Biograde, Anjiga, 215p.

Egypt. J. Hort. Vol. 44, No. 1 (2017)
Smolen S and Sady, W. (2010) Effect of plant biostimulation with pentakeep $\mathrm{v}$ fertilizer and nitrogen fertilization on the content of macroand micronutrients in spinach. J.Elementol., 15 (2), 343- 53.

Solange, L.M. and Rezende, M.O. (2008) Capillary Electrophoresis (CE): A powerful tool to characterize humic acid (HA). J. Brazil Chemical Society, 19, 24-28.

Stanton, K.M., Weeks, S. S., Dana, M. N. and Mickelbart, M.V. (2010) Light exposure and shade effects on growth, flowering, and leaf morphology of Spiraea alba Du Roi and Spiraea tomentosa L. Hortscience, 45 (12), 1912-1916.

Steel, R.G.D., Torri, J.H. and Dickey, D.A. (1997) Principles and Procedures of Statistics: A Biometrical Approach, $3^{\text {rd }}$ ed,. Mc Graw-Hill, New York.

Taha, R.A., Hassan, H.S.A. and Shaaban, E.A. (2014) Effect of different potassium fertilizer forms on yield, fruit quality and leaf mineral content of Zebda Mango trees. Middle-East Journal of Scientific Research, 21 (3), 518-524.

Wrochna M., Łata, B., Borkowska, B. and Gawrońska, H. (2008) The effect Asahi SL of iostimulators on ornament amaranth (Amaranthus sp.) plants exposed to salinity in growing medium. Monographs series: Biostimulators in modern agriculture, Ornament and Special Plants. Wieś Jutra, pp. 15-32.

(Received 7/ 6/ 2017, accepted 6/8/2017) 
تأثثير الرش الورقي بالمحفز الحيوي أتونك ومصادر مختلفة للبوتاسيوم على نبات السالفيا النامي تحت إضاءةً كاملة وتظليل جزئي التي

آمال عبد الخالق محمد هيكل

قسم بساتين الزينة ـ كلية الزر اعة ـ جامعة القاهرة - القاهرة - مصر.

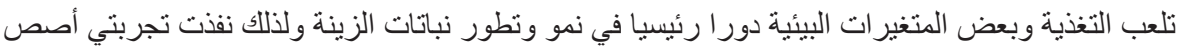

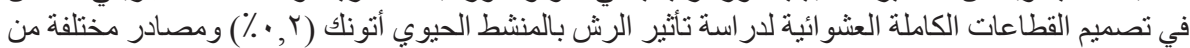

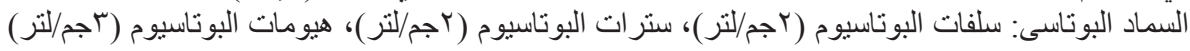

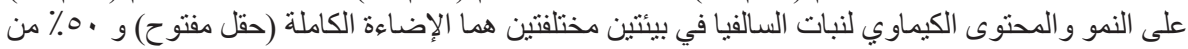

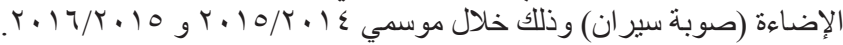

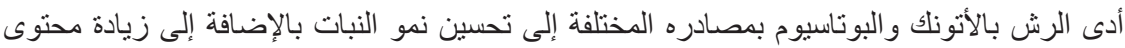

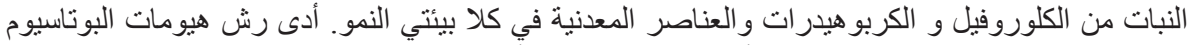

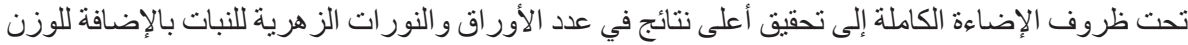

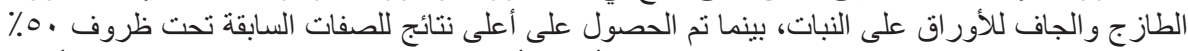

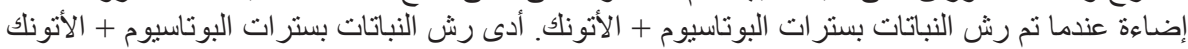

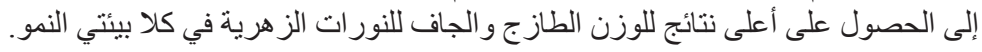

تفوقت النباتات النامية تحت ظروف ـه ٪ إضاءة في صفات ارتفاع النبات و المساحة الفردية للأور اق، بينما

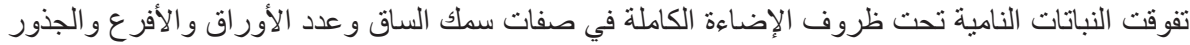

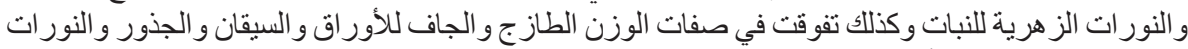
بالإضافة إلى محتوى الأور اق من الكلوروفيل و الكربو هيدر ات و العناصر التون المعدنية. 